\title{
Characterization of the Stones Used on Walls in Teos Hellenistic Period
}

\author{
Y. POLAT ${ }^{a, *}$ AND N. TAMSU SELli ${ }^{b}$ \\ ${ }^{a}$ Anadolu University, Faculty of Letters, Department of Archaeology, Classical Archaeology, Eskisehir, 26470, Turkey \\ ${ }^{b}$ Eczacibasi Building Products Co. VitrA Innovation Center Bozuyuk, Bilecik, Turkey
}

\begin{abstract}
Teos, one of the twelve Ion cities, is located in the of Sığacık neighborhood Seferihisar district, $60 \mathrm{~km}$ southwest of Izmir. The city, on the southern coast of the peninsula Erythrea and Izmir, is the bottleneck of the gulf sea of Samos. West of the city Erythrai (Ildırı), north Klazomenai (Urla), the south island of Samos is located in the southeast of the city of Colophon. The main city is on the black neck which is surrounded by filled gulf formerly named as Teos Gulf, now west of the gulf. In ancient times the city was surrounded by walls for defense purposes. The city walls provide important information about both political and economical structure of the city. Teos walls of Hellenistic Period around 65 hectares of area is surrounded by the city for about $4 \mathrm{~km}$. In this study stone samples which were used in Hellenistic Period have been characterised. Stone samples have been analysed by the following methods: field observations (visual examinations), scanning electron microscope equipped with energy dispersive X-ray spectroscopy, X-ray diffraction and chemical analysis X-ray fluorescence methods. These methods provided us determination of stone properties.
\end{abstract}

DOI: 10.12693/APhysPolA.129.517

PACS/topics: 81.05.Je

\section{Introduction}

Teos ancient city, which is located in Seferihisar District Slğacık Neighborhood within the borders of İzmir province at the present time, was an important city in the center of Ionia Region due to its geographical location. Due to its location, it was an important city in terms of military, politics and commerce with two sheltered harbors it had in ancient period. The perimeters of the city was fortified with a defense line as it was the case for many cities of the ancient period. The subject of this study is to create the characterization of the stones used in fortification walls of Teos City in Hellenistic Period. The city walls comprise towers supporting the defense line and gates providing access to the city, wall-walks constituting the walking areas of soldiers, and battlements for observation and for shooting arrows. We can learn from the writers of ancient period that it is surrounded with walls of Archaic Period on the Acropolis named Kocakır Hill. The early information on the walls of the city from the Archaic Period are obtained from Herodotus [1], who was a writer from the ancient period. As for the Classic Period walls of the city, Thucydides made Ref. [2].

The walls surrounding the city, which can be traced both from the surface and with the excavations, were mostly constructed in the Hellenistic Period (Fig. 1). The first modern research regarding the fortification walls of the city was conducted by W.J. Hamilton, who visited the city in 1836. C. Texier, who visited the city in 1830s,

*corresponding author; e-mail: ypolat@anadolu.edu.tr

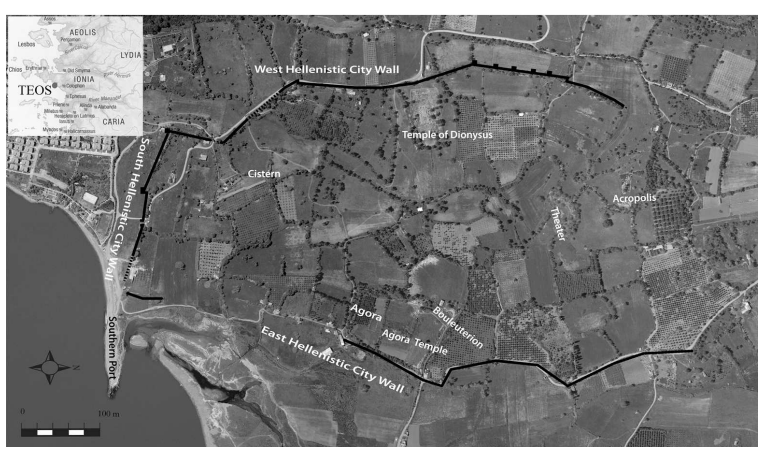

Fig. 1. Ionia region, city of Teos and the locations the analysis samples are taken from.

also had determinations regarding the archaeological remains in the city and the walls of the city. The first detailed information regarding the walls were acquired in the excavations conducted in the city in 1924 by French researchers. A $3.30 \mathrm{~m}$ exploration was conducted on the inner side of the wall located to the west of the Temple of Dionysus and base levels were reached [3].

The level of the fortification wall was reached with the excavations conducted between 1962 and 1965 by Boysal and Ögün (Fig. 2). As a result of the excavations, ceramics dating back to 6th century B.C., as well as dense Hellenistic Period findings, were obtained down to the base level. In the section about $0.80 \mathrm{~m}$ from the base of the wall to the bedrock, findings dating from 6th century B.C. to the Protogeometric period were identified [4-7]. Between 1993 and 1996, surface researches were conducted by Tuna in the city and in 1993, especially the city plan created by French researchers regarding the city walls in 1924 was reviewed and this plan was updated [8]. The previous researchers stated the length 


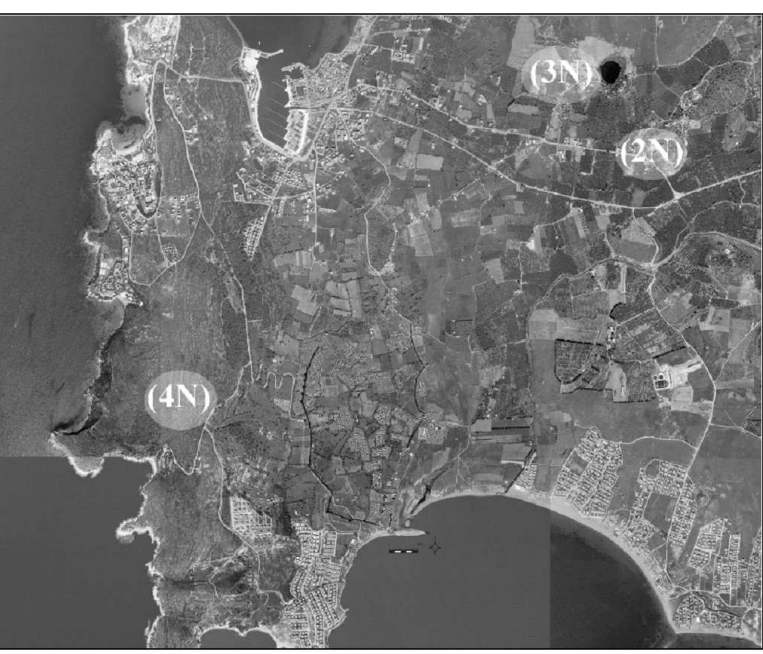

Fig. 2. Satellite view of Teos and the locations the analysis samples are taken from.

of the fortification walls as $6 \mathrm{~km}$ in the determinations based on the sections of the fortification walls traceable from the surface $[9,10]$. Researching the city walls constitutes an important part of the excavation studies led by Musa Kadığlu since 2010 [11-13]. This study was also supported by Anadolu University Scientific Research Projects Commission under the grant no. 1307E289. The surface researches and excavation studies aimed at the detection of city walls conducted for this purpose put forth important results. Both the archaeological excavations and the geophysical studies prove that the fortification walls of the city of Teos from Hellenistic Period surround an area of 65 ha approximately and the city by continuing for about $4 \mathrm{~km}$.

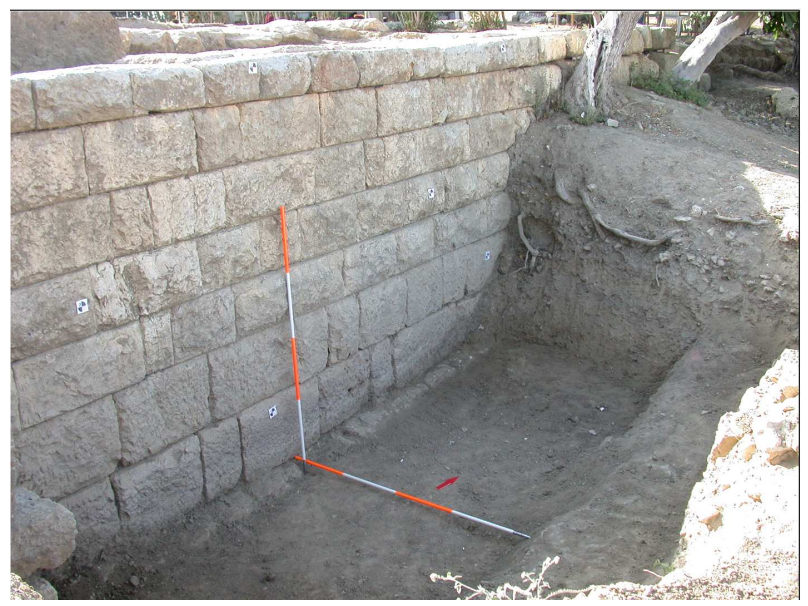

Fig. 3. Hellenistic city wall west of the Temple of Dionysus.

The northern walls, which constitute the border of the northern section of the city, are the sections where the Hellenistic walls of the city can hardly be traced. Due to the expansion of the city towards this area in Roman era and the old Siğacik road passing over the walls after- wards, it cannot be traced wholesomely. Nonetheless, the remains of the wall can be seen partly on the old Sığacık road. The Eastern walls, having $800 \mathrm{~m}$ length, continue along the coast. The narrowest section of the city are the southern walls with $380 \mathrm{~m}$ length. $250 \mathrm{~m}$ of these walls can be traced. The Western walls have $1100 \mathrm{~m}$ length. The fortification wall detected to the west of the Temple of Dionysus is the most intact of the fortification walls detected in the city.

The fortification walls constituting the walls of the city were constructed in isodomic form and their front faces have bossages. In order to designate whether the stones constituting the fortification walls were acquired from around the city or brought from another quarry, samples were taken for analysis from the fortification walls, from the vicinities of the ancient city and from the ancient quarry $3 \mathrm{~km}$ northeast to the city covering an $200 \mathrm{~m}$ diameter area around the lake named Karagöl.

\section{Experimental procedure}

The fortification wall stone samples taken from different sections were compared to the stone samples taken from Tarla Depo Önü, Kayalık, Karagöl and West Necropolis. Samples taken from South Wall, Necropolis Gate are referred to as $1 \mathrm{~T}$, samples taken from West Wall, South of Herodotus Gate are referred to as 2T, samples taken from East Wall, the walls located to the east of Agora are referred to as 3T, samples taken from the rocky area of the field located to the east of the West Wall Excavation House are referred to as $1 \mathrm{~N}$, samples taken from the rocky field located on Sığacık-Seferihisar road are referred to as $2 \mathrm{~N}$, samples taken from the rocky field located on Sı ğacık-Seferihisar road are referred to as $3 \mathrm{~N}$, samples taken from the Necropolis area located to the Southwest of Teos City are referred to as 4N (Figs. 1, 3). Chemical characterisation was carried out by means of wavelength dispersive X-ray fluorescence spectrometry (XRF), using a Philips model PW 2400 XRF instrument fitted with an $\mathrm{Rh}$ white fluorescent tube. The samples were prepared as fused beads using a Philips PERL'X3 instrument. The crystalline phases in the fired samples were determined by XRD analyses (Figs. 4, 5). For XRD analyses, sintered samples were scanned from $2 \alpha=5^{\circ}$ to

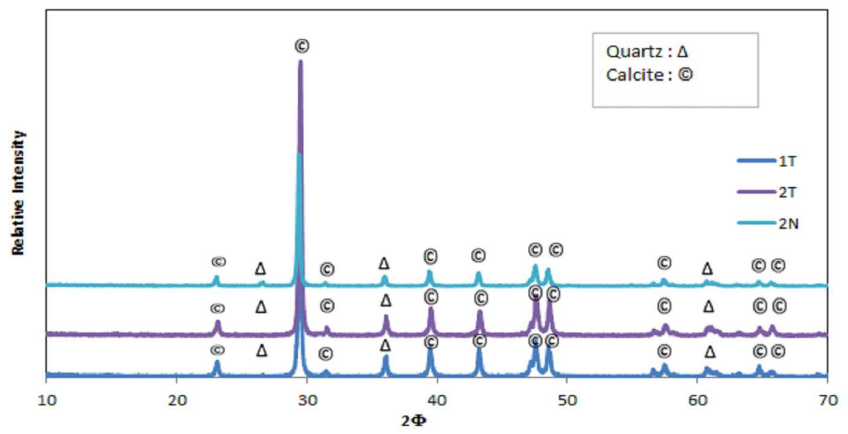

Fig. 4. Comparison of the XRD analyses of Teos stone walls samples. 


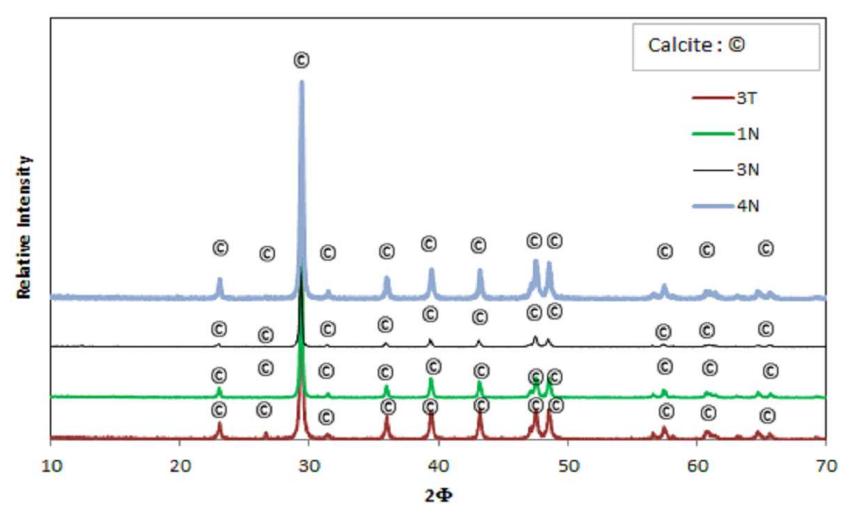

Fig. 5. Comparison of the XRD analyses of Teos stone walls samples.

$70^{\circ}$, at a scanning speed of $2^{\circ} / \mathrm{min}$, using a Rigaku Rint 2000 Series diffractometer with $\mathrm{Cu} K_{\alpha}$ radiation at $40 \mathrm{kV}$ and $30 \mathrm{~mA}$. Microstructural observations were performed on selected fired samples using a scanning electron microscope (EVO-50, Carl-Zeiss, Germany).

\section{Results and discussion}

Chemical analyses of the compositions are shown in Table I. When the results of the chemical analysis are inspected, it is seen that the main chemical component of all the samples is $\mathrm{CaO}$ and this is followed by $\mathrm{SiO}_{2}$ in small amounts. $\mathrm{Fe}_{2} \mathrm{O}_{3}$ and $\mathrm{P}_{2} \mathrm{O}_{5}$ are found as impurities in trace amounts.

In order to understand the compatibility of stones of the walls with designated areas, samples are also subjected to X-ray diffraction (XRD) analysis. The stone samples of South Wall (1T) and the stone samples of West Wall (2T) are compatible with the stones from the rocky area (2N) (Fig. 4). Quartz and calcite structures are apparent in both sample sets. This shows that the south and the west walls are made of stones acquired from the rocky area.

Chemical composition of the stones samples used on walls.

TABLE I

\begin{tabular}{c|c|c|c|c|c|c|c|c|c}
\hline \hline & \multicolumn{10}{c}{ Components $(\mathrm{wt} \%$} \\
\cline { 2 - 10 } sample & $\mathrm{MgO}$ & $\mathrm{Al}_{2} \mathrm{O}_{3}$ & $\mathrm{SiO}_{2}$ & $\mathrm{~K}_{2} \mathrm{O}$ & $\mathrm{CaO}$ & $\mathrm{Fe}_{2} \mathrm{O}_{3}$ & $\mathrm{P}_{2} \mathrm{O}_{5}$ & $\mathrm{Na}_{2} \mathrm{O}$ & L.O.I \\
\hline $1 \mathrm{~T}$ & 0.1923 & 0.3307 & 0.6620 & 0.0448 & 54.9133 & 0.2335 & 0.0179 & - & 43.61 \\
$2 \mathrm{~T}$ & 0.3796 & - & 0.1976 & 0.0203 & 56.1722 & 0.1233 & - & - & 43.10 \\
$3 \mathrm{~T}$ & 0.3553 & 0.7819 & 2.3126 & 0.1532 & 52.7762 & 0.4193 & 0.1386 & - & 43.06 \\
$1 \mathrm{~N}$ & 0.4283 & 0.3541 & 0.6193 & - & 54.71 & 0.1917 & - & 0.1101 & 43.58 \\
$2 \mathrm{~N}$ & 0.2875 & 0.3736 & 2.6574 & 0.0688 & 53.8608 & 0.3115 & 0.0325 & - & 42.11 \\
$3 \mathrm{~N}$ & 0.3515 & - & 0.9325 & - & 54.8498 & 0.7488 & 0.1275 & - & 43.00 \\
$4 \mathrm{~N}$ & - & - & 0.5030 & 0.0213 & 55.9971 & 0.2591 & 0.0145 & - & 43.20
\end{tabular}

According to XRD analysis, east wall store samples (3T) are compatible with the stones in Tarla Depo Önü $(1 \mathrm{~N})$ and Karagöl $(3 \mathrm{~N})$ region and the West Necropolis (4N) (Fig. 5). According to XRD analysis, the calcite structure is the observable main crystalline phase in all 4 sample sets. This shows that the east walls are made of stones acquired from the Tarla Depo Önü, Karagöl and West Necropolis region.

The images regarding the microstructures of the stones taken from Tarla Depo Önü (1N), Kayalık (2N), Karagöl $(2 \mathrm{~N})$ and West Necropolis $(4 \mathrm{~N})$ are seen in Fig. 6. As can be seen from these images, microstructures do not have any indications such as sintering in granules, stating sintering in high temperatures etc.

\section{Conclusions}

In order to designate whether the stones constituting the fortification walls were acquired from around the city or brought from another quarry, samples were taken for analysis from the fortification walls, from the vicinities of the ancient city and from the ancient quarry $3 \mathrm{~km}$ northeast to the city covering a $200 \mathrm{~m}$ diameter area around the lake named Karagöl. As a result of the studies conducted, it is seen that the samples taken are compatible with the samples taken from the vicinities of the city. The fact

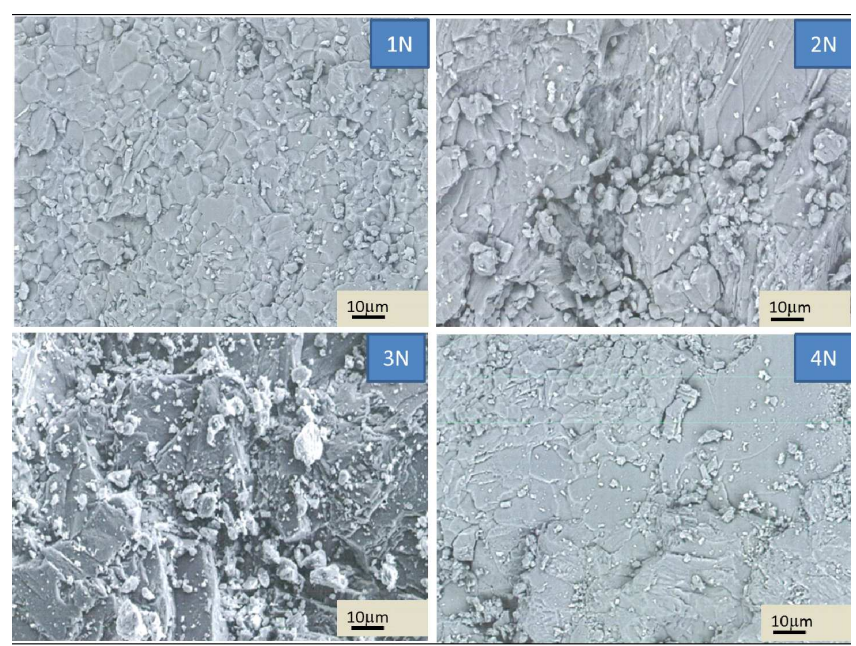

Fig. 6. The microstructure analysis of the stone samples which are denoted $1 \mathrm{~N}-2 \mathrm{~N}-3 \mathrm{~N}$ and $4 \mathrm{~N}$.

that the stones used in the fortification walls, which were constructed in Hellenistic Period around the city for defense and which required great amounts of stone, were obtained from vicinities reducing both the cost and the workmanship. Ceramic samples revealed from soundings to determine the Teos Hellenistic Period city walls and soil/clay samples from nearby river bank were analysed 
both archaeologically and archaeometrically. Archaeometric examinations of ceramic samples which were obtained and selected from Teos archaeological region have provided important clues about the local and regional level to the production of ceramics [14].

\section{References}

[1] Herodotos, Historiai/Histories, Ed. A.D. Godley, The Loeb Classical Library, Harvard University Press, London 1927.

[2] Thucydides, History of the Peleponnesian War, Thomas Hobles, London 1843.

[3] Y. Béquignon, A. Laumonier, Fouilles de Teos (Excavations of Teos), Bull. de Correspondance Hellénique, Paris 49, 281 (1925) (in French).

[4] Y. Boysal, B. ve Ögüun, Türk Arkeoloji Dergısı 12, 12 (1964) (in Turkish).

[5] B. Öğün, Türk Arkeoloji Dergısı 13, 115 (1964) (in Turkish).

[6] Y. Boysal, Türk Arkeoloji Dergısı 12, 5 (1965) (in Turkish).
[7] N. Tuna, Araştırma Sonuçları Toplantısı 12, 167 (1995) (in Turkish).

[8] C. Texier, Description Géographique, Historique et Archéologique des Provinces et des Villes de la Chersonnése d'Asie (Geographic, Historical, and Archaeological Description of Provinces and Cities of Chersonese in Asia), Typoqraphie de Firmin Didot, Institut de France, Paris 1882 (in French).

[9] Y. Ersoy, E. Koparal, Araştırma Sonuçları Toplantısı 25, 47 (2008) (in Turkish).

[10] M. Kadıoğlu, M. Adak M, C. Özbil, D.Ö. Yalçın, Y. Polat, Kazı Sonuçları Toplantısı 33, 429 (2012) (in Turkish).

[11] M. Kadıŏlu, M. Adak, C. Özbil, S.H. Öztaner, R.T. Polat, Y. Polat, Kazı Sonuçları Toplantısı 34, 211 (2012) (in Turkish).

[12] M. Kadıŏlu, Kazı Sonuçları Toplantısı 36, 437 (2014) (in Turkish).

[13] R.T. Polat, A.A. Akyol, Y.K. Kadıŏlu, Selevcıa ad Calycadnvm 5, 221 (2015) (in Turkish). 